\title{
Safety and Efficacy of Autologous Platelet-rich Fibrin on Graft Uptake in Myringoplasty: A Randomized Controlled Trial
}

\author{
Nithin Prakasan Nair ${ }^{1}$ Arun Alexander $^{1} \quad$ B. Abhishekh ${ }^{1}$ Jyotirmay S. Hegde ${ }^{1}$ Sivaraman Ganesan $^{1}$ \\ Sunil Kumar Saxena ${ }^{1}$ \\ ${ }^{1}$ Department of ENT, Jawaharlal Institute of Postgraduate Medical \\ Education and Research, Pondicherry, Tamil Nadu, India \\ Int Arch Otorhinolaryngol 2019;23:77-82. \\ Address for correspondence Arun Alexander, MS (ENT), DNB, \\ Department of ENT, Jawaharlal Institute of Postgraduate Medical \\ Education and Research (JIPMER), Dhanvantari Nagar, Pondicherry, \\ Tamil Nadu, 605006, India \\ (e-mail: nithinprakasannair.2008@gmail.com).
}

\begin{abstract}
Keywords

- myringoplasty

- tympanic membrane

- platelet-rich fibrin

- graft uptake

Introduction Chronic suppurative otitis media is a common ailment in developing countries, and it generally presents with otorrhea and hearing loss. Different surgical procedures have been used to treat otitis media; among them is myringoplasty, which is a procedure that includes repair of the tympanic membrane. Platelet concentrates have been used widely in different types of wounds and are found to improve wound healing. Hence, the use of platelet-rich fibrin in myringoplasty will also improve the tympanic membrane healing.

Objectives To assess the safety and efficacy of autologous platelet-rich fibrin on graft uptake in myringoplasty.

Methods Eighty-six patients were observed during the study period of two years. Forty-three patients in the study group underwent myringoplasty aided with plateletrich fibrin, and 43 patients in the control group went through the same procedure but without the platelet-rich fibrin. The patients were observed for three months postoperatively by a blinded observer.

Results A total of $4.7 \%$ of the patients in the study group had postoperative infection, compared with a rate of $19 \%$ in the control group $(p=0.039)$. The graft uptake success rate was found to be $97.7 \%$ in the study group as compared with $81 \%$ in control group $(p=0.012)$. The results were found to be statistically significant.

Conclusion Being autologous in nature, and by comparing the groups, platelet-rich fibrin is safe for patients. The postoperative graft uptake rate is better in cases in which plateletrich fibrin was used. The postoperative infection rate was also lower in the same group.
\end{abstract}

\section{Introduction}

Chronic suppurative otitis media is a chronic infection of the middle ear and the mastoid cavity, which usually presents with purulent otorrhea for more than six weeks, otalgia or hearing loss.

The global burden of chronic suppurative otitis media is estimated to be around 65 to 300 million patients, $60 \%$ of which experience significant hearing loss. The prevalence of chronic suppurative otitis media is higher in developing countries $^{1}$ and $\sim 6 \%$ of the Indian population suffers from chronic ear disease.

Myringoplasty is a surgical procedure for repair of the tympanic membrane. The middle ear cavity can be safeguarded from exposure to the external environment by repairing the tympanic membrane, hence preventing further exposure to pathogens. The graft uptake success rate may vary from $64-96 \% .^{2}$ As per an audit published by the Royal received

September 13, 2017

accepted

February 18, 2018

published online

May 9, 2018
DOI https://doi.org/

10.1055/s-0038-1649495. ISSN $1809-9777$.
Copyright (C) 2019 by Thieme Revinter

Publicações Ltda, Rio de Janeiro, Brazil
License terms

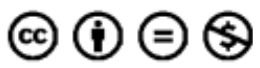


College of Surgeons of England, in 1993, and a prospective study done during the period of 2008 to 2012 the success rate of graft uptake was found to be $80 \%{ }^{3}$ A six-year prospective study conducted by Karela et al found the graft uptake success rate to be as high as $91.6 \%{ }^{4}$ After analyzing the database of 15 years and over 3,775 surgical procedures, the Swedish National Registry estimated the graft uptake success rate to be around $88.5 \% .^{5}$ A comparative study done by Murugendrappa et al found graft uptake to have a success rate of $74 \%$ in myringoplasty done by conventional underlay technique. ${ }^{6}$

Platelet concentrates have been used extensively by maxillofacial surgeons, plastic surgeons, and orthopedic surgeons to augment wound healing. The different platelet concentrates that have been studied are platelet-rich plasma and platelet-rich fibrin. ${ }^{7}$

Platelet-rich fibrin is a second-generation platelet concentrate, which is rich in platelets, cytokines, growth factors, and leukocytes that are trapped and released over a period. It serves as a resorbable membrane that offers both mechanical and inflammatory protection to the tympanic membrane. It accelerates cell proliferation and matrix remodeling. Being an autologous biomaterial, it does not induce any undesirable tissue reactions. Moreover, it is easy, quick and cheap to produce, and can easily be manipulated during surgical procedures. The role of platelet-rich fibrin in the repair of traumatic tympanic membrane perforation has been studied as well. As it has strong elastic fibers rich with growth factors, it is considered an ideal patch material for tympanic membrane perforation. Leukocytes embedded in the platelet-rich fibrin scaffold also play a role in the release of growth factors, immune regulation, antimicrobial response and matrix remodeling in wound healing. ${ }^{8}$

This study was done to analyze the efficacy of platelet-rich fibrin to aid graft uptake success rate and the safety of its use in myringoplasty.

\section{Objectives}

To assess the safety and efficacy of autologous platelet-rich fibrin on graft uptake in myringoplasty

\section{Methodology}

The present study was conducted between August 2015 and January 2017 in a tertiary care center. The hypothesis was that the use of autologous platelet-rich fibrin is safe in myringoplasty and improves the success rate of graft uptake in myringoplasty.

The sample size was calculated based on a study that reported the success rate of graft uptake in myringoplasty as $64 \%{ }^{9}$ The uptake rate was expected to improve a further $25 \%$ over routine myringoplasty to $89 \%$. The minimum required sample size was calculated using a 95\% level of confidence and $80 \%$ power, and it was found to be 43 in each group, study and control. (Using the Open Epi statistical software).

A total of 86 patients, who were above the age of 18 and planned for myringoplasty, were enrolled. Patients with comorbidities like diabetes and hypertension were excluded. The study was designed to be a prospective, randomized controlled trial. Patients were randomized into two groups by simple randomization. The random sequence was generated using a random allocation software to allocate participants to either of the two groups. The allocation was concealed using sequentially numbered sealed opaque envelopes. The envelopes were then given to the scrub nurse and were opened at the time of recruitment of the eligible participants.

In the study group, a sample of $10 \mathrm{ml}$ of blood was collected from each patient in a sterile container just before the surgery. The blood sample was centrifuged using a table top centrifuge at 2,700 rpm for 12 minutes. Centrifugation resulted in the formation of a fibrin clot (platelet-rich fibrin) in the middle of the tube (between the RBC layer at the bottom and plasma at the top) (-Fig. 1). The plasma layer is deficient in platelets. This middle layer was separated on a laminar flow hood, under aseptic precautions (-Fig. 2). ${ }^{10}$ We were able to collect platelet-rich fibrin from all patients in the study group. Around $1-2 \mathrm{~mL}$ of platelet-rich fibrin was collected from each patient.

Patients in both groups, control and study, underwent myringoplasty by postaural approach, using the underlay technique and temporalis fascia graft. In the study group, after placing the graft and repositioning the tympanomeatal flap, the platelet-rich fibrin was placed as a plug over the sealed perforation (-Fig. 3). In the control group, gel foam was kept over the sealed perforation, after repositing the flap. Both groups of patients received antibiotics, as per the routine protocol followed by the department.

Following the surgery, graft uptake was assessed by an otoscope at three months postsurgery by a blinded observer (-Fig. 4). The safety of platelet-rich fibrin was investigated with respect to immediate postoperative infection in both groups, during routine follow-up. Patients presenting with history of ear discharge, irrespective of bacteriological culture, were considered to be postoperative infection in both groups. All patients who presented with discharge were treated with antibiotics. One out of 43 patients in the control group was lost to follow-up.

\section{Statistical Analysis}

The distribution of categorical variables, such as gender, postoperative infection rate and graft uptake status, was expressed in terms of frequency and percentage. Age was expressed as mean and standard deviation. The age analysis was performed with independent Student t-test. The data of continuous variables, like duration of dry ear and intraoperative perforation size, were converted to categorical variables, which were expressed in terms of frequency and percentage. The comparison of these categorical variables between the two groups was done by means of the Chi Square test.

All statistical analysis was performed with the SPSS Statistics package 17.0 (SPSS Inc., Chicago, IL, USA). A $p$ value $<0.05$ was considered significant.

\section{Results}

One patient was lost to follow-up during the study. Hence, the analysis was done as per protocol, excluding the patient 


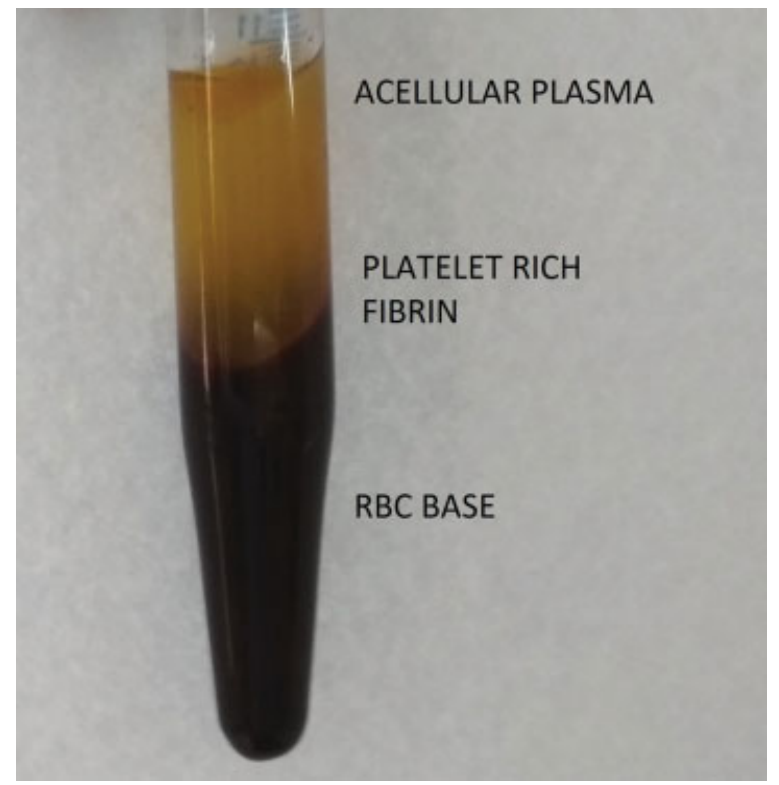

Fig. 1 Post-centrifugation: layers of centrifuged blood.

who was lost to follow-up. Seventy-one of the patients recruited in the study were younger than 40 years of age. There was a predominance of female patients among both groups. On assessing the duration of dry ear, it was found that the majority of patients had more than six weeks of dry ear in both groups. Among the groups, the majority of patients had tympanic membrane perforation involving three or more quadrants. The ossicles were found to be intact in all patients, intraoperatively. Nine patients were found to have middle ear inflammation (-Table $\mathbf{1}$ ).

A total of $4.7 \%$ of the patients in whom the platelet-rich fibrin was used was found to have an infection, whereas in the control group, $19 \%$ of the patients had postoperative infection. (-Table 2).

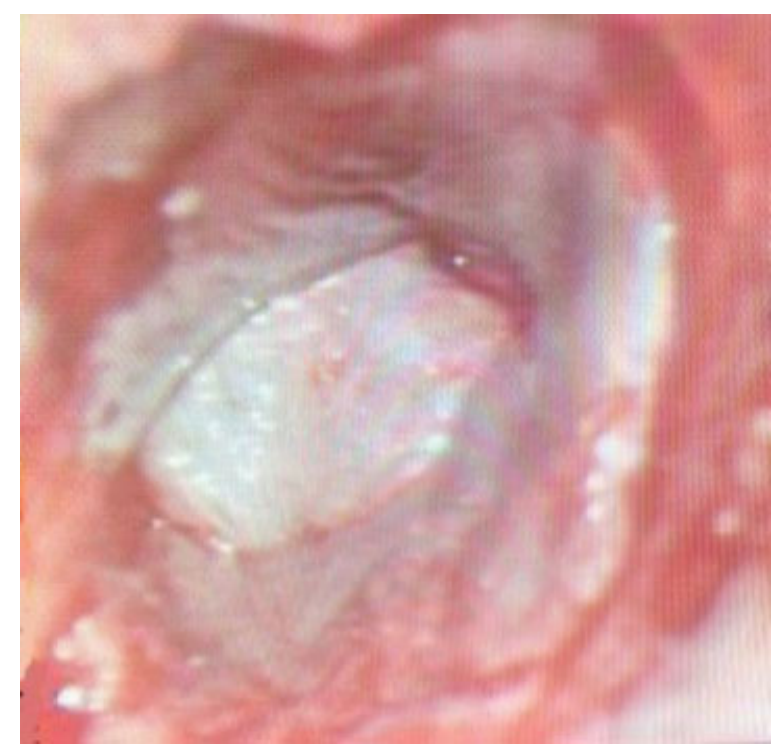

Fig. 3 Platelet-rich fibrin clot kept as a plug over the sealed perforation.

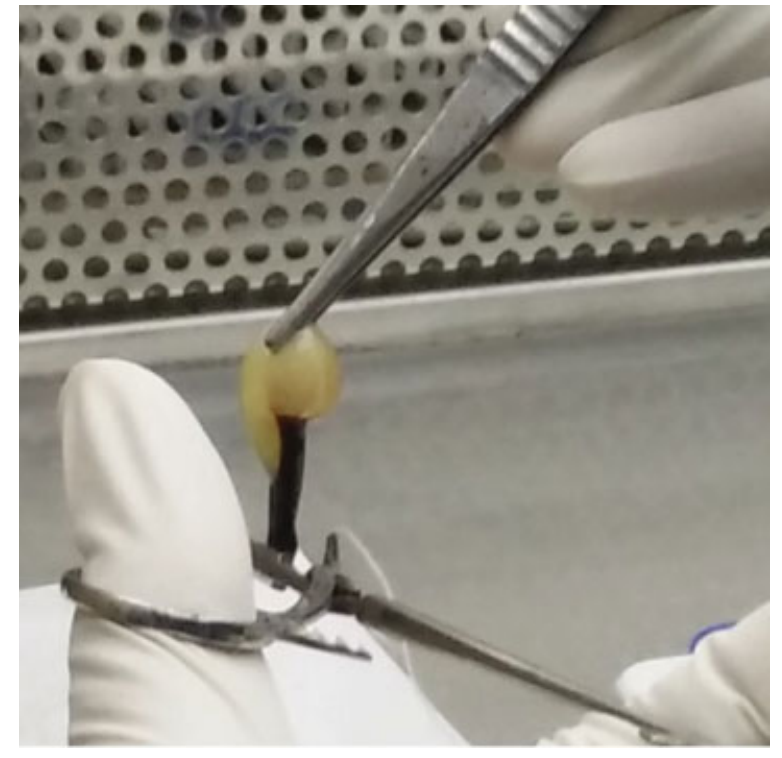

Fig. 2 Platelet-rich fibrin clot.

At three months of follow-up, $97.7 \%$ of patients had successful graft uptake. Meanwhile, $81 \%$ of control cases had successful graft uptake. (- Table 3 ).

Of the nine patients who had had intraoperative middle ear inflammation, all of them had successful graft uptake, and none presented with postoperative infection. Four of these patients belonged to the study group, and five to the control group.

Most patients had perforation involving three or more quadrants. Among the 34 patients in the control group, 27 (79\%) had successful graft uptake. However, all patients in the study group had successful graft uptake (-Table 4 ).

Seven out of 34 patients (21\%) in the control group had postoperative infection while only 1 out of 28 patients in the

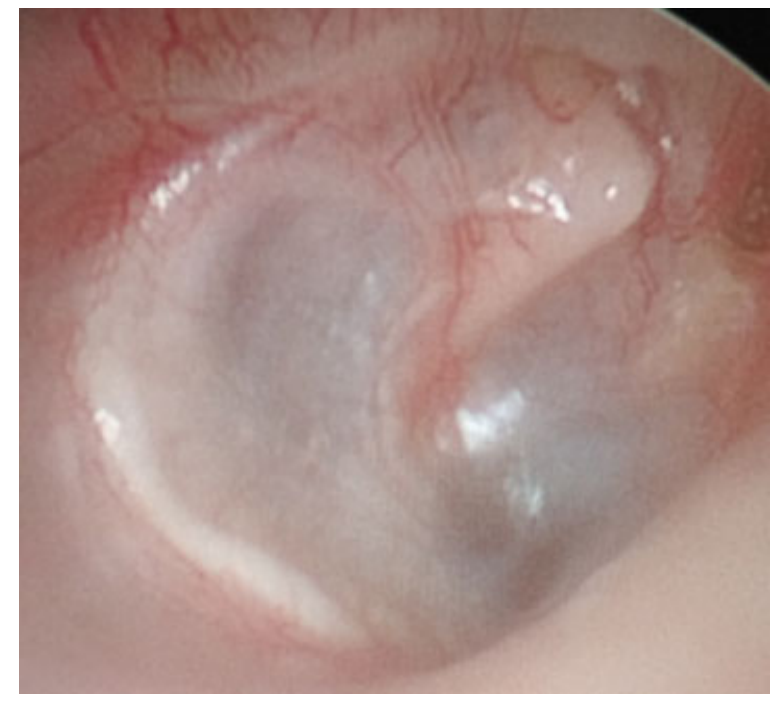

Fig. 4 Neotympanum, at three months of follow-up. 
80 Safety and Efficacy of Autologous Platelet-rich Fibrin Nair et al.

Table 1 Basic parameters in control and study group

\begin{tabular}{|l|l|l|l|l|}
\hline SI No & Parameters & $\begin{array}{l}\text { PRF used } \\
(\boldsymbol{n}=43) \\
(\text { Study) }\end{array}$ & $\begin{array}{l}\text { PRF not used } \\
(\boldsymbol{n}=\mathbf{4 2}) \\
\text { (Control) }\end{array}$ & $p$-value \\
\hline 1 & Age (years) & $31.91 \pm 8.662$ & $29.12 \pm 9.572$ & 0.163 \\
\hline 2 & Gender (male/female) & $19 / 24$ & $20 / 22$ & 0.751 \\
\hline 3 & $\begin{array}{l}\text { Ear dry duration in weeks } \\
(0-2 / 2-6 />6)\end{array}$ & $3 / 12 / 28$ & $1 / 10 / 31$ & 0.516 \\
\hline 4 & $\begin{array}{l}\text { Ear side } \\
(\text { right/left) }\end{array}$ & $12 / 31$ & $17 / 25$ & 0.222 \\
\hline 5 & Intra operative middle ear inflammation & $5 / 38$ & $4 / 38$ & 0.753 \\
\hline 6 & $\begin{array}{l}\text { Number of tympanic membrane quadrants } \\
\text { involved by perforation } \\
1 / 2 / 3 / 4\end{array}$ & $1 / 14 / 10 / 18$ & $2 / 6 / 6 / 28$ & 0.082 \\
\hline
\end{tabular}

Abbreviation: PRF, platelet-rich fibrin.

${ }^{*}$ Age is expressed in mean years \pm standard deviation.

Table 2 Comparison of postoperative infection among study and control group

\begin{tabular}{|l|l|l|l|l|}
\hline $\begin{array}{l}\text { SI } \\
\text { No }\end{array}$ & $\begin{array}{l}\text { Platelet- } \\
\text { rich } \\
\text { fibrin }\end{array}$ & $\begin{array}{l}\text { Post-operative } \\
\text { infection } \\
\text { present }\end{array}$ & $\begin{array}{l}\text { No } \\
\text { post-operative } \\
\text { infection }\end{array}$ & Total \\
\hline 1 & Used & $2(4.7 \%)$ & $41(95.3 \%)$ & 43 \\
\hline 2 & Not used & $8(19 \%)$ & $34(81 \%)$ & 42 \\
\hline
\end{tabular}

$p$-value $=0.039$.

Table 3 Comparison of postoperative graft uptake among study and control group

\begin{tabular}{|l|l|l|l|l|}
\hline $\begin{array}{l}\text { SI } \\
\text { No }\end{array}$ & $\begin{array}{l}\text { Platelet- } \\
\text { rich } \\
\text { fibrin }\end{array}$ & $\begin{array}{l}\text { Postoperative } \\
\text { graft uptake } \\
\text { present }\end{array}$ & $\begin{array}{l}\text { No } \\
\text { postoperative } \\
\text { graft uptake }\end{array}$ & Total \\
\hline 1 & Used & $42(97.7 \%)$ & $1(2.3 \%)$ & 43 \\
\hline 2 & Not used & $34(81 \%)$ & $8(19 \%)$ & 42 \\
\hline
\end{tabular}

$p$-value $=0.012$.

study group had postoperative infection (3.6\%). All patients had successful graft uptake at the end of 3 months (-Table 5).

Among the 4 patients ( $1=$ control group; $3=$ study group) who had a history of dry ear for less than 2 weeks, only the patient in the control group had any infection.

Table 4 Comparison of graft uptake among study and control group, who had intraoperatively perforation involving three or more quadrants

\begin{tabular}{|l|l|l|l|l|}
\hline $\begin{array}{l}\text { SI } \\
\text { No }\end{array}$ & $\begin{array}{l}\text { Platelet- } \\
\text { rich } \\
\text { fibrin }\end{array}$ & $\begin{array}{l}\text { Postoperative } \\
\text { graft uptake } \\
\text { present }\end{array}$ & $\begin{array}{l}\text { No } \\
\text { postoperative } \\
\text { graft uptake }\end{array}$ & Total \\
\hline 1 & Used & $28(100 \%)$ & 0 & 28 \\
\hline 2 & Not used & $27(79 \%)$ & $7(21 \%)$ & 34 \\
\hline
\end{tabular}

$p$-value $=0.011$ by Fischer Exact t-test.
Table 5 Comparison of postoperative infection among study and control group, in patients who had intra-operatively perforation involving more than three quadrants

\begin{tabular}{|l|l|l|l|l|}
\hline $\begin{array}{l}\text { SI } \\
\text { No }\end{array}$ & $\begin{array}{l}\text { Platelet- } \\
\text { rich } \\
\text { fibrin }\end{array}$ & $\begin{array}{l}\text { Postoperative } \\
\text { infection } \\
\text { present }\end{array}$ & $\begin{array}{l}\text { No } \\
\text { postoperative } \\
\text { infection }\end{array}$ & Total \\
\hline 1 & Used & $1(3.6 \%)$ & $27(96.4 \%)$ & 28 \\
\hline 2 & Not used & $7(21 \%)$ & $27(79 \%)$ & 34 \\
\hline
\end{tabular}

$p$-value $=0.05$ by Fischer Exact t-test.

Patients in the study group had successful graft uptake and had no postoperative infection.

Among the 59 patients (31 in the control group; 28 in the study group) who had a history of dry ear of more than 6 weeks, the graft uptake success rate was found to be $87.1 \%$ in the control group, as opposed to $100 \%$ in the study group (-Table 6). None in the study group had postoperative infection; while, $12.9 \%$ of controls had postoperative infection ( - Table 7 ).

Among the 25 patients, (15 in the study group; 10 in the control group) with history of dry ear of less than 6 weeks, the graft uptake success rate was found to be $91.6 \%$ in the study group, as compared with $66.6 \%$ in the control group. The postoperative infection rate was found to be in $8.4 \%$ of the patients in the study group and $33.6 \%$ in the control group. ( $p>0.05$; not statistically significant)

Table 6 Comparison of graft uptake among study and control group in patients with history of ear dry duration more than six weeks from the time of surgery

\begin{tabular}{|l|l|l|l|l|}
\hline $\begin{array}{l}\text { SI } \\
\text { No }\end{array}$ & $\begin{array}{l}\text { Platelet- } \\
\text { rich } \\
\text { fibrin }\end{array}$ & $\begin{array}{l}\text { Post-operative } \\
\text { graft uptake } \\
\text { present }\end{array}$ & $\begin{array}{l}\text { No } \\
\text { post-operative } \\
\text { graft uptake }\end{array}$ & Total \\
\hline 1 & Used & 28 & 0 & 28 \\
\hline 2 & Not used & $27(87.1 \%)$ & $4(12.9 \%)$ & 31 \\
\hline
\end{tabular}

$p$-value $=0.029$ (Fischer Exact t-test). 
Table 7 Comparison of post-operative infection among study and control group in patients with history of ear dry duration more than six weeks from the time of surgery

\begin{tabular}{|l|l|l|l|l|}
\hline $\begin{array}{l}\text { SI } \\
\text { No }\end{array}$ & $\begin{array}{l}\text { Platelet- } \\
\text { rich } \\
\text { fibrin }\end{array}$ & $\begin{array}{l}\text { Post-operative } \\
\text { infection } \\
\text { present }\end{array}$ & $\begin{array}{l}\text { No } \\
\text { post-operative } \\
\text { infection }\end{array}$ & Total \\
\hline 1 & Used & 0 & $28(100 \%)$ & 28 \\
\hline 2 & $\begin{array}{l}\text { Not } \\
\text { used }\end{array}$ & $4(12.9 \%)$ & $27(87.1 \%)$ & 31 \\
\hline
\end{tabular}

$p$-value $=0.029$ (Fischer Exact t-test).

\section{Discussion}

The analysis of age distribution revealed no statistically significant difference between the study and control groups. The majority of the patients recruited were young, with $55.7 \%$ of the patients in the 18-30 years age group. The majority of the patients recruited for this study were female (54.1\%), which may be considered an indicator of increased treatment seeking behavior amidst young and female patients.

A total of $95.3 \%$ of patients gave history of dry ear with duration of more than two weeks. There were four patients who had had a dry ear for less than 2 weeks. On analyzing the graft uptake success rates, even in patients with dry ear duration of less than 2 weeks, the success rates among the study population was $100 \%$. Furthermore, there was no postoperative infection. Only one patient in the control group had postoperative infection and graft uptake failure. However, the numbers in either group are too few to comment

On detailed perusal of the available data, it becomes evident that the graft uptake rate was better in cases in which platelet-rich fibrin was used. The graft uptake rate was found to be $97.7 \%$ in the study group as opposed to $81 \%$ in the control group. In other words, there was a difference of $16.7 \%$ between the two groups.

Previous studies had shown a success rate of myringoplasty ranging from 64-96\%. The audit published by the Royal College of Surgeons of England in, 1993, reported a success rate of 65\%, which improved to $80 \%$ in $1997 .{ }^{3}$ A prospective study done by Kamath et al over the period of 2008 to 2012 had found a graft uptake success rate of $80 \%$ among 60 cases. ${ }^{11}$ From this, we can understand that the graft uptake success rate in our study was comparable and almost similar to other studies.

Among all platelet concentrates, platelet-rich plasma has been extensively studied. In otology, it is used for traumatic tympanic membrane perforation, type 1 tympanoplasty, for facial nerve regeneration, etc. The biostimulation effect of platelet-rich plasma on type 1 tympanoplasty studied by Navarrete Álvaro et al showed that platelet-rich plasma stimulates fibroblast and thus, aids in the closure of tympanic membrane perforations. ${ }^{12}$

A study done by Sankaranarayanan et al on platelet-rich plasma-assisted tympanoplasty found that closure rates were better in patients in whom platelet-rich plasma was used, as compared with a control group. They assessed 25 patients in each group and found a closure rate of $92 \%$ in the study group and $70 \%$ in the control group. ${ }^{13}$

Topical application of autologous platelet-rich plasma was analyzed by El-Anwar et al. They concluded that topical autologous platelet-rich plasma is safe and enhances the healing of chronic tympanic membrane perforation and avoid infections. ${ }^{14}$ In another study by El Anwar et al, patients with posttraumatic tympanic membrane, they freshened the margins and applied autologous platelet-rich plasma in an hourglass manner. The study was done on an office basis. They found that in $84 \%$ of the cases the tympanic membrane had healed completely. They concluded in their study that office-based platelet-rich plasma myringoplasty is an effective and safe minimally invasive procedure. ${ }^{15}$

A study was conducted by Habesoglu et al in 2011 among 32 patients with acute tympanic membrane perforation. He concluded that the use of platelet-rich fibrin accelerated the tympanic membrane closure. ${ }^{16}$ An animal study conducted by Ensari et al assessed the healing rate of traumatic perforation in rats. He found that the mean healing time of the perforation was decreased in the study group, in which the perforation was closed by platelet-rich fibrin. ${ }^{17}$

In this same study, we find that the graft uptake success rate was increased by $16.7 \%$ in patients in whom platelet-rich fibrin assisted tympanoplasty was done. When we separately analyzed patients with perforations involving three or more quadrants, the graft uptake rate in the study group was found to be $100 \%$, in comparison to $79 \%$ in the control group.

It is also observed that the postoperative infection rates were fewer in the study group as compared with the control group. In fact, there was a difference of $14.3 \%$ concerning postoperative infection rate. Furthermore, on assessing patients with tympanic membrane perforation involving three or more perforations, the postoperative infection rates were found to be lower in the study group.

In patients with middle ear inflammation, the graft uptake rate was found to be $100 \%$ in both groups. No patient presented with postoperative infection in either group.

It has also been seen that in larger perforations, the use of platelet-rich fibrin increased the graft uptake chances and reduced the intraoperative infection rate. The same results were observed regarding dry ear duration. The majority of patients belonged to the group with history of dry ear for more than 6 weeks.

Garin et al found that platelet-rich fibrin can be used safely for middle ear packing without any adverse effects, such as those observed with collagen derived from porcine skin. He concluded that it could be used as a substitute to collagen. $^{18}$

In a review article by Sarkar, ${ }^{2}$ it was found that filling the cavity with platelet-rich fibrin following third molar extraction led to a 10 -fold reduction in the risk of osteomyelitis. ${ }^{2}$

We have seen that platelet-rich fibrin improves the graft uptake rate. This also serves as evidence pertaining to the safety aspect of platelet-rich fibrin, as it prevents the exposure of the middle ear to the environment. Moreover, on analyzing the results, we see that there is a decreased incidence of postoperative infection in patients in whom 
platelet-rich fibrin was used as compared with the control group. Being autologous, platelet-rich fibrin is safe, cheap and easily available. It is not expected to cause any allergic/ tissue reactions, which can occur with allogenous plateletrich fibrin. Based on the above studies, it is hypothesized that the antimicrobial effect would have been the cause of the reduced infection rate in the study group.

This study was a randomized control trial. There have been very few studies that have analyzed the safety and efficacy of platelet-rich fibrin in otology to date. The sample size was achieved. As an autologous material was used, there were no undesirable reactions. However, long-term efficacy and safety have not been addressed in this study.

\section{Conclusion}

As there was no significant number of postoperative infections in platelet-rich fibrin aided myringoplasty, it is considered safe for use in myringoplasty. The procedure of production of platelet-rich fibrin is simple; it is cheap, safe and easily available. The chances of graft uptake are better when myringoplasty is aided with platelet-rich fibrin, especially in case of larger tympanic membrane perforation. The graft uptake success rate was observed to be better in patients belonging to different groups of dry ear duration. The reduced postoperative infection rate in the platelet-rich fibrin-aided myringoplasty group may suggest the antimicrobial effect of platelet-rich fibrin. However, further studies are required to support this fact.

Hence, we conclude that platelet-rich fibrin is safe and efficacious in myringoplasty.

Conflicts of Interest

The authors have no conflicts of interest to declare.

\section{Ethical Approval}

All procedures involving human participants were in accordance with the ethical standards of the institutional and/or national research committee, and with the 1964 Helsinki Declaration and its amendments or comparable ethical standards. Ethical clearance was obtained from the institutional Ethics Committee and the trial was registered in a clinical trial registry in India. A signed informed consent was obtained from all individual participants included in the study.

\section{References}

1 Schilder AGM, Chonmaitree T, Cripps AW, et al. Otitis media. Nat Rev Dis Primers 2016;2:16063
2 Sarkar S. A review on the history of tympanoplasty. Indian J Otolaryngol Head Neck Surg 2013;65(Suppl 3):455-460

3 Ryan RM, Brown PM, Cameron JM, Fowler SM, Grant HR, Topham JH. Royal College of Surgeons comparative ENT audit 1990. Clin Otolaryngol Allied Sci 1993;18(06):541-546

4 Karela M, Berry S, Watkins A, Phillipps JJ. Myringoplasty: surgical outcomes and hearing improvement: is it worth performing to improve hearing? Eur Arch Oto-Rhino-Laryngol Off J Eur Fed OtoRhino-Laryngol Soc EUFOS Affil Ger Soc Oto-Rhino-Laryngol -. Head Neck Surg 2008;265:1039-1042

5 Berglund M, Florentzson R, Fransson M, et al. Myringoplasty Outcomes From the Swedish National Quality Registry. Laryngoscope 2017;127(10):2389-2395

6 Murugendrappa MA, Siddappa PN, Shambulingegowda A, Basavaraj GP. Comparative Study of Two Different Myringoplasty Techniques in Mucosal Type of Chronic Otitis Media. J Clin Diagn Res 2016;10(02):MC01-MC03

7 Choukroun JI, Braccini F, Diss A, Giordano G, Doglioli P, Dohan DM. [Influence of platelet rich fibrin (PRF) on proliferation of human preadipocytes and tympanic keratinocytes: A new opportunity in facial lipostructure (Coleman's technique) and tympanoplasty?] Rev Laryngol Otol Rhinol (Bord) 2007;128(1-2):27-32

8 Gür ÖE, Ensari N, Öztürk MT, et al. Use of a platelet-rich fibrin membrane to repair traumatic tympanic membrane perforations: a comparative study. Acta Otolaryngol 2016;136(10): 1017-1023

9 Lee P, Kelly G, Mills RP. Myringoplasty: does the size of the perforation matter? Clin Otolaryngol Allied Sci 2002;27(05): 331-334

10 Sunitha Raja V, Munirathnam Naidu E. Platelet-rich fibrin: evolution of a second-generation platelet concentrate. Indian J Dent Res 2008;19(01):42-46

11 Kamath MP, Sreedharan S, Rao AR, Raj V, Raju K. Success of myringoplasty: our experience. Indian J Otolaryngol Head Neck Surg 2013;65(04):358-362

12 Navarrete Álvaro ML, Ortiz N, Rodriguez L, et al. Pilot study on the efficiency of the biostimulation with autologous plasma rich in platelet growth factors in otorhinolaryngology: otologic surgery (tympanoplasty type I). ISRN Surg 2011;2011:451020

13 Sankaranarayanan G, Prithviraj V, Kumar V. A study on efficacy of autologous platelet rich plasma in myringoplasty. Online J Otolaryngol 2013;3:36

14 El-Anwar MW, El-Ahl MAS, Zidan AA, Yacoup MA-RA-S. Topical use of autologous platelet rich plasma in myringoplasty. Auris Nasus Larynx 2015;42(05):365-368

15 El-Anwar MW, Elnashar I, Foad YA. Platelet-rich plasma myringoplasty: A new office procedure for the repair of small tympanic membrane perforations. Ear Nose Throat J 2017;96(08):312-326

16 Habesoglu M, Oysu C, Sahin S, et al. Platelet-rich fibrin plays a role on healing of acute-traumatic ear drum perforation. J Craniofac Surg 2014;25(06):2056-2058

17 Ensari N, Gür ÖE, Öztürk MT, Süren D, Selçuk ÖT, Osma Ü. The effect of platelet-rich fibrin membrane on the repair of perforated tympanic membrane: an experimental study. Acta Otolaryngol 2017;137(07):695-699

18 Garin P, Mullier F, Gheldof D, Dogne J-M, Putz L, Van Damme JP. Platelet-rich fibrin (PRF): an autologous packing material for middle ear microsurgery. B-ENT 2014;10(01):27-34 